\title{
Feasibility of in situ hybridisation with chromosome specific DNA probes on paraffin wax embedded tissue
}

\author{
E P J Arnoldus, E J Dreef, I A Noordermeer, M M Verheggen, R F Thierry, A C B \\ Peters, C J Cornelisse, M Van der Ploeg, A K Raap
}

\begin{abstract}
The feasibility was studied of in situ hybridisation using chromosome specific DNA probes on paraffin wax embedded normal and malignant tissues from different organs. Both isolated nuclei and 5 $\mu \mathrm{m}$ sections were used in in situ hybridisation experiments with biotinylated repetitive DNA probes specific for the centromeric regions of chromosomes 1 and 17 . The hybridisation results were visualised with peroxidase-diaminobenzidine. The optimal pretreatments with sodium thiocyanate and pepsin were experimentally defined for the different tissues.

Although interphase cytogenetics on paraffin wax embedded tissue is possible, the results indicate that it has its limitations, compared with investigations on fresh tumour tissue.
\end{abstract}

Tumour cells often show numerical or structural chromosomal abnormalities. These aberrations may, in some cases, provide clues to the initial changes which caused the tumour to arise. Such aberrations may also correlate with the behaviour of the tumour and have prognostic value, in which case the findings could be used to determine clinical management. A great deal of effort has therefore been invested in the cytogenetic analysis of malignancies. The classic technique of karyotyping Giemsa banded metaphase chromosomes is still mostly used to generate detailed information on the chromosomal content of neoplastic cells. For solid tumours, however, several disadvantages are inherent in this approach. ${ }^{1}$

First, tumour tissue often has to be cultured to obtain sufficient metaphases. A relatively low success rate of only $60 \%$ in obtaining good metaphases is reported. ${ }^{2}$ When successful, the number of metaphase spreads is often small, and because of culture effects it is questionable whether these are representative of the original tumour cell population. As a consequence knowledge of cytogenetic aberrations in solid tumours is poor when compared with that in haematological malignancies.

An alternative method for the study of chromosomal abnormalities is the measurement of abnormal DNA content of cell nuclei using flow cytometry. This technique is extremely rapid and results are representative of the cells in the sample. In 1983 Hedley described the use of nuclei isolated from formalin fixed, paraffin wax embedded tissue in DNA flow cytometry. ${ }^{3}$ Because of the relative simplicity of the technique, many investigators have attempted to use tumour material from the (large) paraffin wax archives to correlate abnormal DNA content with prognosis for a large variety of tumours. In his review article published in 1989 Hedley mentions more than 100 of these studies. ${ }^{4}$ A major drawback, however, is the "limited cytogenetic sensitivity": a "small" change in nuclear DNA content like the loss of one complete chromosome often remains undetected. ${ }^{5}$ Furthermore, when abnormal DNA content is found, the question remains as to what cytogenetic changes have occurred.

A third technique for the study of cytogenetic changes in solid tumours is in situ hybridisation using chromosome specific DNA probes. DNA sequences can be detected in interphase nuclei ("interphase cytogenetics") ${ }^{6}$ as well as in metaphase spreads, thereby obviating the need to culture tumour material. A limitation of interphase cytogenetics is that it only generates information for those chromosome regions to which the probes can hybridise. Application of interphase cytogenetics has been described for solid tumours of bladder, ${ }^{78}$ breast, ${ }^{9}$ stomach, ${ }^{10}$ and brain. ${ }^{11}$ In all these studies nuclei isolated from fresh tumour material were examined. Studies on paraffin wax embedded tissues have so far been restricted to tissue sections of bladder carcinomas ${ }^{12}$ and testicular tumours. ${ }^{1314} \mathrm{~A}$ disadvantage of the use of 5 or $10 \mu \mathrm{m}$ thick tissue sections is that the number of hybridisation signals per nucleus will be an underestimation of the actual copy number of the target chromosome because a significant number of nuclei will be truncated. This was elegantly shown by Hopman et al, who found that the number of signals per nucleus increased with section thickness. ${ }^{12}$ Interphase cytogenetics on tissue sections at best gives an impression of the highest copy number that can be present in a certain subpopulation.

For an accurate assessment of the copy number of a chromosome, intact nuclei can be isolated from $50 \mu \mathrm{m}$ paraffin wax sections and used for interphase cytogenetics. Parallel sections of $5 \mu \mathrm{m}$ can be used for histopathological identification of the specific tumour tissue areas, which can then be removed with a

Academic Hospita

PO Box 9600, 2300 RC

Accepted for publication 22 May 1991 
small, hollow corer for the isolation of tumour nuclei. ${ }^{1516}$

If interphase cytogenetics could be used routinely on paraffin wax embedded material this would imply that archival tumour material could be (re-)studied for possible chromosomal abnormalities. As the histopathological grading of this material and the clinical outcome is usually known, potential correlations with the chromosomal aberrations might be studied relatively easily.

\section{Methods}

Blocks of archival, paraffin wax embedded, normal and neoplastic tissue of brain, lung, breast, testis, kidney and colon were studied. The tumour group consisted of a testis seminoma, a meningioma, and adenocarcinomas of lung, breast, kidney and colon. The tissues had been routinely fixed in $4 \%$ buffered formaldehyde for $\mathbf{4 8}$ hours, except for the brain samples which had been fixed for two weeks. The sections used had a thickness of $5 \mu \mathrm{m}$ and 50 $\mu \mathrm{m}$.

\section{PREPARATION OF NUCLEI SUSPENSIONS AND BUCKET-SLIDES}

The preparation of a suspension of single nuclei was essentially performed, as described by Hedley et $a l .^{3}$ In short, $50 \mu \mathrm{m}$ paraffin wax sections were dewaxed and rehydrated. The tissue was treated with $0.5 \%$ pepsin ( $\mathrm{P}-7000$ Sigma) for 30 minutes at $37^{\circ} \mathrm{C}$ in $0.01 \mathrm{M}$ or 0.2 $\mathrm{M} \mathrm{HCl}$ and centrifuged. The pellet was washed with distilled water and resuspended in $3 \mathrm{ml}$ of distilled water; after sedimentation for a few minutes at $1 \times g$ the supernatant, which contained single nuclei in suspension, was transferred to another tube. After this procedure the nuclei were fixed in several changes of a mixture of $70 \%$ ethanol. Then a few drops of the fixed nuclei suspension were added to $1 \mathrm{ml}$ of $70 \%$ acetic acid and centrifuged on to glass slides cleaned with ethanolether for 10 minutes at $135 \times g$ using a bucketcentrifuge. ${ }^{17}$ To remove dirt the slides were dipped in $70 \%$ acetic acid for 15 seconds. The slides were allowed to dry overnight. The next day they were washed for one hour in phosphate buffered saline (PBS) and then for one hour in distilled water. The slides were dehydrated and stored at room temperature until use within one month.

\section{PROBES AND BIOTIN LABELLING}

The probes used in this study were specific for the (peri)centromeric regions of chromosome 1 $(\mathrm{pUCl} \cdot 77)^{18}$ and 17 (p17H8). ${ }^{19}$ These probes were labelled with biotin-16-dUTP by standard nick translation. The labelled DNA was ethanol-precipitated with salmon sperm DNA and yeast RNA as carrier. The precipitate was dissolved in a mixture of $60 \%$ deionised formamide $/ 2 \times$ SSC $(1 \times$ SSC $=0.15 \mathrm{M}$ $\mathrm{NaCl}, 0.015 \mathrm{M}$ sodium citrate) and distilled water to a probe concentration of $5 \mathrm{ng} / \mu \mathrm{l}$.

PRETREATMENTS AND IN SITU HYBRIDISATION Several pretreatment protocols were compared for optimal in situ hybridisation results. An optional pretreatment consisted of incubating the slides in distilled water, $1 \mathrm{M} \mathrm{NaSCN}, 1 \mathrm{M}$ $\mathrm{LiCl}$, or $4 \mathrm{M}$ guanidium chloride in a shaking waterbath at $80^{\circ} \mathrm{C}$ for 10 minutes. The slides were then digested with $0.5 \%$ pepsin in either $0.01 \mathrm{M}$ or $0.2 \mathrm{M} \mathrm{HCl}$ at $37^{\circ} \mathrm{C}$. The length of the pepsin treatment varied from 15 to 60 minutes. Optional steps after the pepsin digestion were postfixation with $1 \%$ formaldehyde or $4 \%$ paraformaldehyde, and incubation with $1 \%$ hydroxylammoniumchloride. The slides were rinsed with PBS and dehydrated. Then $5 \mu \mathrm{l}$ of hybridisation mixture was added under a coverslip of $18 \times 18 \mathrm{~mm}^{2}$. The probe and the target DNA were denatured simultaneously for 10 minutes at $80^{\circ} \mathrm{C}$. In situ hybridisation was allowed to take place overnight at $37^{\circ} \mathrm{C}$ in a moist chamber with $60 \%$ formamide and $2 \times$ SSC.

\section{IMMUNOCYTOCHEMICAL DETECTION}

After in situ hybridisation the slides were washed three times for five minutes each in $60 \%$ formamide $/ 2 \times \mathrm{SSC}(\mathrm{pH} \mathrm{7.0)}$ at room temperature. They were rinsed in $4 \times \mathrm{SSC} / 0.05 \%$ Tween-20 and preincubated with $4 \times \mathrm{SSC} /$ $5 \%$ non-fat dry milk. Immunological detection consisted of three consecutive incubations of 30 minutes at $37^{\circ} \mathrm{C}$ : avidin-D ( 1 in 100 ), biotinated polyclonal goat-anti-avidin (1 in 100), and avidin-peroxidase ( 1 in 100) in $4 \times$ SSC/ $5 \%$ non-fat dry milk. After washing in $4 \times$ SSC $/ 0.05 \%$ Tween-20, PBS, and $50 \mathrm{mM}$ TRIS-HCl ( $\mathrm{pH} \mathrm{7.4)} \mathrm{the} \mathrm{slides} \mathrm{were} \mathrm{incubated}$ in the dark for 10 minutes at room temperature with a solution of $0.05 \%$ diaminobenzidine, $0.05 \% \mathrm{H}_{2} \mathrm{O}_{2}, 1 \mathrm{mM}$ imidazole in $50 \mathrm{mM}$

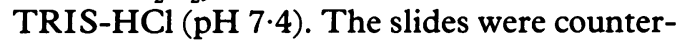
stained with Mayer's haematoxylin, dehydrated, and embedded with Fluoromount (BDH, England).

\section{Results}

ISOLATION OF NUCLEI

The isolation of nuclei following the Hedley procedure resulted in different yields of individual nuclei for the different tissues. As this was probably caused by differences in cellularity of the sections, the number of $50 \mu \mathrm{m}$ sections of the various tissues used for isolation was adjusted. The percentage of nuclei which attached to the glass slide after the bucketcentrifuge spin depended on the coating of the slides and the fluid in which the nuclei were centrifuged. Optimal combinations are: $70 \%$ acetic acid with ethanol/ether cleaned slides and $70 \%$ ethanol with poly-L-lysine coated slides. The loss of normal nuclei from the glass slides during the in situ hybridisation procedure was the same for each of these combinations and amounted to about $30 \%$ of the original number deposited. Because of its ease the first combination was used in further experiments. A remarkable difference between normal and tumour tissues was the fact that tumour nuclei which were isolated with $0.5 \%$ pepsin in $0.2 \mathrm{M} \mathrm{HCl}$ detached from the slides during the hybridisation procedure, while 
Table 1 Results of interphase cytogenetics on normal tissue sections using optimal protocol

\begin{tabular}{|c|c|c|c|c|c|c|c|}
\hline \multirow[b]{2}{*}{ Tissue } & \multirow[b]{2}{*}{$N a S C N$} & \multirow[b]{2}{*}{$0.5 \%$ Pepsin } & \multirow[b]{2}{*}{ Morphology } & \multicolumn{2}{|c|}{ Signals } & \multicolumn{2}{|c|}{ Evaluable } \\
\hline & & & & 1 & 17 & 1 & 17 \\
\hline $\begin{array}{l}\text { Brain } \\
\text { Colon } \\
\text { Kidney } \\
\text { Lung } \\
\text { Breast } \\
\text { Testis }\end{array}$ & $\begin{array}{l}+ \\
+ \\
+ \\
+ \\
+ \\
-\end{array}$ & $\begin{array}{l}60 \text { mins } 0.2 \mathrm{M} \mathrm{HCl} \\
30 \text { mins } 0.2 \mathrm{M} \mathrm{HCl} \\
60 \text { mins } 0.2 \mathrm{M} \mathrm{HCl} \\
60 \text { mins } 0.2 \mathrm{M} \mathrm{HCl} \\
60 \text { mins } 0.2 \mathrm{M} \mathrm{HCl} \\
15 \text { mins } 0.2 \mathrm{M} \mathrm{HCl}\end{array}$ & $\begin{array}{l}+ \\
+ \\
+1- \\
+ \\
+1- \\
+\end{array}$ & $\begin{array}{l}++ \\
+ \\
+ \\
+1- \\
+1- \\
+\end{array}$ & $\begin{array}{l}+1- \\
+1- \\
+1- \\
- \\
+1-\end{array}$ & $\begin{array}{l}+ \\
+1- \\
+ \\
+1- \\
+1- \\
+\end{array}$ & $\begin{array}{l}- \\
- \\
- \\
- \\
+ \\
+1-\end{array}$ \\
\hline
\end{tabular}

Table 2 Results of interphase cytogenetics on tumour tissue sections using optimal protocol

\begin{tabular}{|c|c|c|c|c|c|c|c|}
\hline \multirow[b]{2}{*}{ Tumour } & \multirow[b]{2}{*}{$N a S C N$} & \multirow[b]{2}{*}{$0.5 \%$ Pepsin } & \multirow[b]{2}{*}{ Morphology } & \multicolumn{2}{|c|}{ Signals } & \multicolumn{2}{|c|}{ Evaluable } \\
\hline & & & & 1 & 17 & 1 & 17 \\
\hline $\begin{array}{l}\text { Brain } \\
\text { Colon } \\
\text { Kidney } \\
\text { Lung } \\
\text { Breast } \\
\text { Testis }\end{array}$ & $\begin{array}{l}- \\
+ \\
+ \\
- \\
+ \\
-\end{array}$ & $\begin{array}{l}45 \text { mins } 0.01 \mathrm{M} \mathrm{HCl} \\
45 \text { mins } 0.2 \mathrm{M} \mathrm{HCl} \\
60 \text { mins } 0.2 \mathrm{M} \mathrm{HCl} \\
45 \text { mins } 0.2 \mathrm{M} \mathrm{HCl} \\
30 \text { mins } 0.2 \mathrm{M} \mathrm{HCl} \\
15 \text { mins } 0.01 \mathrm{M} \mathrm{HCl}\end{array}$ & $\begin{array}{l}+ \\
+ \\
+ \\
++ \\
+1-\end{array}$ & $\begin{array}{l}+ \\
+ \\
+ \\
++ \\
+ \\
+\end{array}$ & $\begin{array}{l}- \\
+1- \\
+1- \\
+1- \\
+ \\
+\end{array}$ & $\begin{array}{l}+1- \\
+1- \\
+ \\
+1- \\
+1- \\
+\end{array}$ & $\begin{array}{l}- \\
+1- \\
- \\
+1- \\
+1- \\
+\end{array}$ \\
\hline
\end{tabular}

tumour nuclei isolated in $0.01 \mathrm{M} \mathrm{HCl}$ and normal nuclei isolated with either procedure did not. Therefore, the isolations were performed for all tissues in $0.01 \mathrm{M} \mathrm{HCl}$.

EFFECTS OF DIFFERENT PRETREATMENTS

To find an optimal balance between in situ hybridisation signals and morphology, variations were performed in the treatments of the sections and the isolated nuclei on the slides beforehand. Longer pepsin treatments provided, in general, better accessibility of the chromosomal DNA in the nuclei for the probes, but poorer morphology. The pepsin digesting conditions iike time and $\mathrm{pH}(0.01 \mathrm{M}$ or $0.2 \mathrm{M} \mathrm{HCl}$ ) were varied for the different tissues and the best ones are summarised in tables $1-4$. The pepsin pretreatment on nuclei preparations was milder than the one for tissue sections, as a logical consequence of the fact that the nuclei had already been in contact with pepsin during isolation. RNase treatment before the addition of pepsin did not improve the in situ hybridisation results.

According to Hopman et al, ${ }^{12}$ heating the slides in an $80^{\circ} \mathrm{C}$ waterbath in $1 \mathrm{M} \mathrm{NaSCN}$ or in distilled water before pepsin digestion gave better results on thin paraffin sections. NaSCN would, as a chaotropic agent, loosen bonds between nucleic acids and proteins, making the very compact chromatin proteins more accessible for pepsin. In our hands, sections of testis, brain, and lung displayed a dramatic loss in morphological detail and no increase in signal

Table 3 Results of interphase cytogenetics on isolated nuclei from paraffin wax embedded normal tissue using optimal protocol

\begin{tabular}{|c|c|c|c|c|c|c|c|}
\hline \multirow[b]{2}{*}{ Tissue } & \multirow[b]{2}{*}{ NaSCN } & \multirow[b]{2}{*}{$0.5 \%$ Pepsin } & \multirow[b]{2}{*}{ Morphology } & \multicolumn{2}{|c|}{ Signals } & \multicolumn{2}{|c|}{ Evaluable } \\
\hline & & & & 1 & 17 & 1 & 17 \\
\hline Brain & + & $60 \operatorname{mins} 0.2 \mathrm{M} \mathrm{HCl}$ & $+1-$ & + & + & + & + \\
\hline Colon & + & $15 \mathrm{mins} 0.2 \mathrm{M} \mathrm{HCl}$ & - & + & + & + & + \\
\hline Kidney & + & $15 \mathrm{mins} 0.2 \mathrm{M} \mathrm{HCl}$ & + & + & + & + & + \\
\hline Lung & + & $60 \mathrm{mins} 0.2 \mathrm{M} \mathrm{HCl}$ & + & + & + & + & + \\
\hline Breast & + & $15 \mathrm{mins} 0.2 \mathrm{M} \mathrm{HCl}$ & + & + & + & + & + \\
\hline Testis & - & $15 \operatorname{mins} 0.2 \mathrm{M} \mathrm{HCl}$ & $+1-$ & + & + & + & + \\
\hline
\end{tabular}

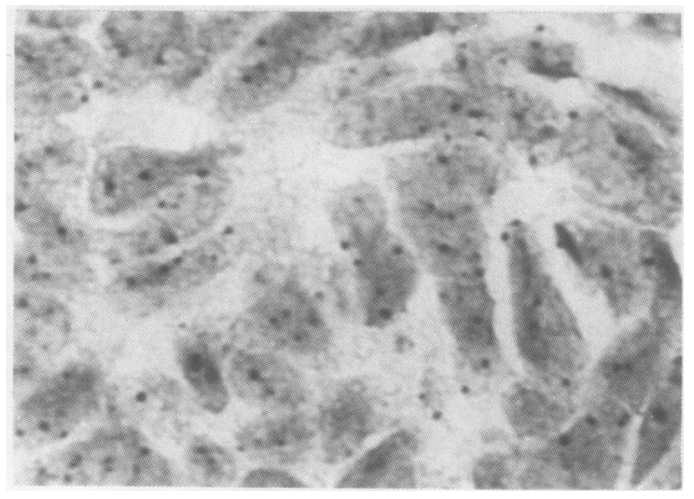

Figure 1 Photomicrograph of a 5 um tissue section of an adenocarcinoma of the lung hybridised with the probe for the chromosome 1 centromeres. Note that, due to contiguous and overlapping nuclei, it is not really possible to evaluate which hybridisation signals belong to which nucleus (Mayer's haematoxylin counterstain).

strength when the NaSCN pretreatment step was included. In contrast, sections of colon, kidney, and breast did show much stronger signals and only a slight loss of morphology. For these tissues we compared the effect of 10 minutes at $80^{\circ} \mathrm{C}$ in chaotropic agents such as 1 $M \mathrm{NaSCN}, 1 \mathrm{M} \mathrm{LiCl}$, or $4 \mathrm{M}$ guanidium chloride with distilled water. $\mathrm{NaSCN}$ and $\mathrm{LiCl}$ gave only slightly better results than guanidium chloride and water. This suggests that the beneficial effect is primarily due to the heating of the sections. Postfixation after the pepsin treatment with $1 \%$ formaldehyde or with $4 \%$ paraformaldehyde did not improve the in situ hybridisation results. Incubation with $1 \%$ hydroxylammoniumchloride to block residual aldehyde groups resulted in somewhat better in situ hybridisation results.

\section{IN SITU HYBRIDISATION ON TISSUE SECTIONS}

Table 1 summarises optimal conditions, morphology assessment, hybridisation signal intensity, and evaluability of the hybridisation signals for chromosome 1 and 17 specific probes on $5 \mu \mathrm{m}$ sections of the various normal tissues investigated. Table 2 summarises the same for hybridisations on tissue sections of tumours. In general, the hybridisation with both probes resulted in distinct signals in a large proportion of nuclei. The necessary pretreatment steps often resulted in poor morphology: loss of intercellular structure, diminished nuclear counterstaining, and so on. As a consequence, for some types of tissue, it was practically impossible to evaluate to which nucleus the signals belonged. The same problem arose when there were many contiguous and overlapping nuclei, such as in lung tumour tissue (fig 1).

IN SITU HYBRIDISATION ON ISOLATED NUCLEI The results on nuclei isolated from normal tissues seemed rather promising (table 3): all tissues gave good signals for both probes used. Tumour nuclei, however, gave less satisfactory results (table 4): only testis and brain gave clear signals that could be evaluated.

For the hybridisations that could be evaluated the number of signals per nucleus was counted in 200 nuclei. The signal/nucleus 
Table 4 Results of interphase cytogenetics on isolated nuclei from paraffin wax embedded tumour tissue using optimal protocol

\begin{tabular}{|c|c|c|c|c|c|c|c|}
\hline \multirow[b]{2}{*}{ Tumour } & \multirow[b]{2}{*}{ NaSCN } & \multirow[b]{2}{*}{$0.5 \%$ Pepsin } & \multirow[b]{2}{*}{ Morphology } & \multicolumn{2}{|c|}{ Signals } & \multicolumn{2}{|c|}{ Evaluable } \\
\hline & & & & 1 & 17 & 1 & 17 \\
\hline $\begin{array}{l}\text { Brain } \\
\text { Colon } \\
\text { Kidney } \\
\text { Lung } \\
\text { Breast } \\
\text { Testis }\end{array}$ & $\begin{array}{l}- \\
+ \\
+ \\
+ \\
+ \\
+\end{array}$ & $\begin{array}{l}45 \text { mins } 0.01 \mathrm{M} \mathrm{HCl} \\
45 \text { mins } 0.2 \mathrm{M} \mathrm{HCl} \\
60 \text { mins } 0.2 \mathrm{M} \mathrm{HCl} \\
60 \text { mins } 0.01 \mathrm{M} \mathrm{HCl} \\
30 \text { mins } 0.01 \mathrm{M} \mathrm{HCl} \\
15 \text { mins } 0.01 \mathrm{M} \mathrm{HCl}\end{array}$ & $\begin{array}{l}+ \\
+1- \\
+1- \\
+ \\
+1- \\
+\end{array}$ & $\begin{array}{l}++ \\
+ \\
+1- \\
+1- \\
+1- \\
++\end{array}$ & $\begin{array}{l}++ \\
+1- \\
+1- \\
+1- \\
+1- \\
++\end{array}$ & $\begin{array}{l}+ \\
+1- \\
+1- \\
+ \\
+\end{array}$ & $\begin{array}{l}+ \\
+1- \\
- \\
+ \\
+1-\end{array}$ \\
\hline
\end{tabular}

distributions are summarised in table 5. About $75 \%$ of the nuclei of normal tissues displayed two signals. This agrees with the findings of previous studies on normal lymphocytes and fibroblasts. ${ }^{92021}$ The relatively high percentage of nuclei of normal breast tissue without any signal for chromosome 17 centromere $(15 \%)$ probably reflects suboptimal hybridisation. Almost $30 \%$ of normal brain nuclei displayed only one large spot after hybridisation with the 17 centromeric probe. The same observation was recently made in nuclei isolated from fresh brain tissue samples, and was explained by somatic pairing of the two centromeres. ${ }^{22}$ The hybridisation on the testis tumour nuclei showed four signals in most of the nuclei for both chromosome 1 and 17 (table 5) (fig 2), reflecting tetraploidy.

\section{Discussion}

Over the past five years in situ hybridisation has been used increasingly more often in cytogenetic studies. One of the main advantages is its applicability to cells in interphase ("interphase cytogenetics"), thereby omitting cumbersome culture procedures. In this study we investigated whether interphase cytogenetics can be applied routinely to tissue that has been fixed in formalin and embedded in paraffin wax as it would permit retrospective analysis of tumours for chromosomal abnormalities.

In situ hybridisation experiments were performed both on nuclei isolated from thick sections and on intact thin sections. For an exact assessment of the copy number of

Table 5 Percentages of nuclei with a certain spot number

\begin{tabular}{|c|c|c|c|c|c|c|}
\hline \multirow[b]{2}{*}{ Tissue } & \multirow[b]{2}{*}{ Chromosome } & \multicolumn{5}{|c|}{ Number of spots per nucleus } \\
\hline & & 0 & 1 & 2 & 3 & 4 \\
\hline \multirow[t]{2}{*}{ Normal brain } & 1 & $1 \cdot 0$ & $15 \cdot 5$ & $76 \cdot 5$ & $6 \cdot 0$ & $1 \cdot 0$ \\
\hline & 17 & 1.5 & & $67 \cdot 0$ & 1.0 & 1.0 \\
\hline \multirow[t]{2}{*}{ Normal colon } & 1 & $2 \cdot 0$ & 15.5 & 77.0 & 5.5 & 0.0 \\
\hline & 17 & $7 \cdot 0$ & 8.5 & $78 \cdot 5$ & 6.0 & 0.0 \\
\hline \multirow[t]{2}{*}{ Normal kidney } & 1 & 5.5 & 15.0 & 73.0 & 6.0 & 0.5 \\
\hline & 17 & 3.5 & 14.0 & 77.5 & 5.0 & 0.0 \\
\hline \multirow[t]{2}{*}{ Normal lung } & 1 & $7 \cdot 0$ & 11.5 & 76.5 & 4.5 & 0.5 \\
\hline & 17 & 6.5 & 15.5 & 73.0 & 0.5 & 0.0 \\
\hline \multirow[t]{2}{*}{ Normal breast } & 1 & 5.5 & 12.5 & 74.5 & 5.0 & 2.5 \\
\hline & 17 & 15.0 & 12.0 & 71.0 & 2.0 & 0.0 \\
\hline \multirow{2}{*}{ Normal testis } & 1 & 2.5 & 12.5 & $77 \cdot 5$ & $6 \cdot 5$ & 1.0 \\
\hline & 17 & 1.5 & $21 \cdot 0$ & $77 \cdot 0$ & 0.5 & 0.0 \\
\hline \multirow[t]{2}{*}{ Brain tumour } & 1 & 0.5 & 12.5 & $85 \cdot 5$ & 1.5 & 0.0 \\
\hline & 17 & 0.0 & 16.5 & $82 \cdot 0$ & 0.5 & 1.0 \\
\hline \multirow[t]{2}{*}{ Testis tumour } & 1 & 1.0 & $4 \cdot 5$ & 16.5 & $22 \cdot 0$ & 56.0 \\
\hline & 17 & 1.5 & 2.5 & $19 \cdot 0$ & $26 \cdot 0$ & $51 \cdot 0$ \\
\hline
\end{tabular}

Two hundred nuclei were evaluated microscopically in isolated nuclei preparations of each tissue after in situ hybridisation with probes specific for the centromeric regions of chromosomes 1 or 17

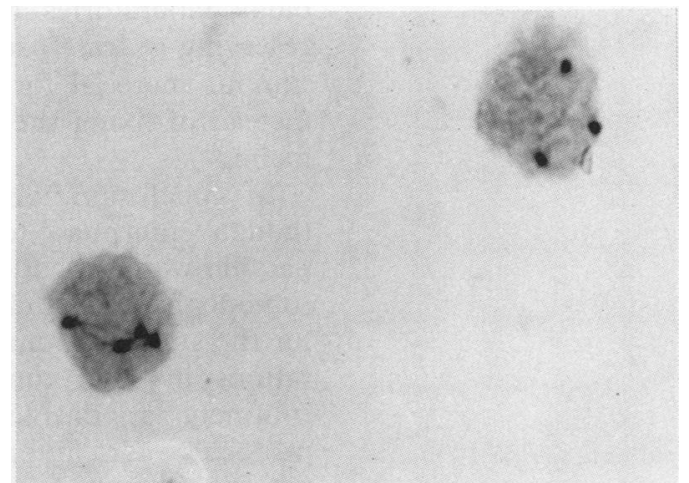

Figure 2 Photomicrograph of nuclei isolated from a seminoma displaying three and four signals per nucleus after hybridisation with the probe for chromosome 17 centromeres (Mayer's haematoxylin counterstain).

chromosomes in tumour cells hybridisations to isolated nuclei are to be preferred. Tissue sections, on the other hand, can provide information on the cell type showing the chromosomal aberration. A disadvantage of using tissue sections, clearly illustrated in our study, is the difficulty of identifying the individual nuclei with their corresponding signals in tissues with a high cellularity. In general, our results seem to favour the use of isolated nuclei (tables 1-4).

Despite extensive variations in the pretreatment protocol we did not succeed in obtaining clear hybridisation signals that could be evaluated in a reproducible and reliable way for all of the tissues investigated. Good results were obtained with testis (tumour) tissue, both on sections and isolated nuclei, while on brain (tumour) tissue good results were obtained only on isolated nuclei. In the other tissues often only part of the nuclei produced signals. The NaSCN pretreatment resulted in a great improvement in hybridisation results, but for some tissues was not compatible with preservation of morphology.

Compared with our practice with fresh tumour tissue, ${ }^{11}$ the results on paraffin wax embedded tissues were, in general, rather disappointing. Firstly, for good results the pretreatments like pepsin and $\mathrm{NaSCN}$ incubations have to be optimised for each individual sample. Secondly, most formalin fixed, paraffin wax embedded tissue displays a lot of autofluorescence. Consequently one is restricted to enzymatic reporter molecules like peroxidase and alkaline phosphatase to visualise the hybridisation products. This limits the possibilities for performing multiple hybridisations simultaneously. Thirdly, the sensitivity of the in situ hybridisation on paraffin wax embedded tissue is significantly lower than on fresh material, on which cosmid probes give good results.

An important disadvantage of using paraffin wax embedded tissue for interphase cytogenetics is the large variability that is introduced during the fixation process. Differences in fixation time, sample size, use of buffered or non-buffered formalin, and so on, will influence the hybridisation success rate. It therefore seems worthwhile for routine path- 
ology laboratories to invest more effort in reserving at least part of the freshly obtained tumour material for interphase cytogenetics, instead of fixing the complete sample in formalin.

In conclusion, our results show that although interphase cytogenetics on archival paraffin wax embedded tissue is feasible, fresh tumour material is clearly still the first choice for the study of numerical chromosome aberrations in solid tumours. Establishment of routinely applicable in situ hybridisation protocols for interphase cytogenetics on paraffin wax embedded tissue requires further research.

1 Teyssier JR. The chromosomal analysis of human solid tumors: a triple challenge. Cancer Genet Cytogenet 1989;37:103-25.

2 Limon J, Dal Cin P, Sandberg AA. Application of long-term collagenase disaggregation for the cytogenetic analysis of human solid tumors. Cancer Genet Cytogenet 1986;23:305-13.

3 Hedley DW, Friedlander ML, Taylor IW, Rugg CA Musgrove EA. Method for analysis of cellular DNA content of paraffin-embedded pathological material using flow cytometry. $J$ Histochem Cytochem 1983;31:1333-5.

4 Hedley DW. Flow cytometry using paraffin-embedded tisue: five years on. Cytometry 1989;10:229-41.

5 Cornelisse CJ, Tanke HJ. Flow cytometry. In: Bibbo M, ed. Comprehensive cytopathology. Philadelphia: WB Saunders, 1991:984-1010.

6 Cremer T, Landegent J, Bruckner A, et al. Detection of chromosome aberrations in the human interphase nucleus by visualization of specific target DNAs with radioactive and non-radioactive in situ hybridization techn diagnosis of trisomy 18 with Ll.84. Hum Genet 1986;74:346-52.

7 Hopman AHN, Ramaekers FCS, Raap AK, et al. In situ hybridization as a tool to study numerical chromosome aberrations in solid bladder tumors. Histochemistry 988;89:307-16.

8 Hopman AHN, Poddighe PJ, Smeets AWGB, et al. Detection of numerical chromosome aberrations in bladde cancer by in situ hybridization. Am J Patho 1989;135:1105-17.
9 Devilee P, Thierry RF, Kievits T, et al. Detection of chromosome aneuploidy in interphase nuclei from human primary breast tumours using chromosome-specific primary breast tumours using chromosome-specifitive DNA probes. Cancer Res 1988;48:5825-30.

10 Van Dekken H, Pizzolo JG, Kelsen DP, Melamed MR. Targeted cytogenetic analysis of gastric tumors by in situ
hybridization with a set of chromosome-specific DNA probes. Cancer 1990;66:491-7.

11 Arnoldus EPJ, Noordermeer IA, Peters ACB, et al. Interphase cytogenetics on brain tumours. Genes, Chromosome and Cancer 1991;3:101-7.

12 Hopman AHN, Van Hooren E, Van de Kaa CA, Vooijs GP Ramaekers FCS. Detection of numerical chromosome aberrations using in situ hybridization in paraffin section of routinely processed bladder cancers. Mod Pathol (in press).

13 Emmerich P, Jauch A, Hofmann M-C, Cremer T, Walt H. Interphase cytogenetics in paraffin-embedded sections from human testicular germ cell tumor xenografts and in corresponding cultured cells. Lab Invest 1989;61:235-42.

14 Corresponding cultured cells. Lab Invest 1989;61:235-42. F. Supernumerary chromosome 1 in interphase nuclei of F. Supernumerary chromosome 1 in interphase nuclei of atypical germ cells in paraffin-embedded h

15 Van Driel-Kulker AMJ, Eysackers MJ, Dessing MTM Ploem JS. A simple method to select specific tumor areas in paraffin blocks for cytometry using incident fluorescence microscopy. Cytometry 1986;7:601-4.

16 Oud PS, Hanselaar AGJM, Reubsaet-Veldhuizen JAM Extraction of nuclei from selected regions in paraffinembedded tissue. Cytometry 1986;7:595-600.

17 Van Driel-Kulker AMI, Mesker WE, Van Velzen I, Tanke HJ, Feichtinger J, Ploem JS. Preparation of monolayer smears from paraffin-embedded tissue for image smears from paraffin-embedded 2 .

18 Cooke HJ, Hindley J. Cloning of human satellite III DNA different components are on different chromosomes. Nucleic Acids Res 1979;6:3177-97.

19 Waye JS, Willard HF. Molecular analysis of a deletion polymorphism in alpha satellite of human chromosome 17: evidence for homologous unequal crossing-over and subsequent fixation. Nucleic Acids Res 1986;14:6915-27.

20 Cremer T, Tessin D, Hopman AHN, Manuelidis L. Rapid interphase and metaphase assessment of specific chromosomal changes in neuroectodermal tumor cells by in situ hybridization with chemically modified DNA probes. Exp Cell Res 1988;176:199-220.

21 Nederlof PM, Van der Flier S, Rap AK, et al. Detection of chromosome aberrations in interphase tumor nuclei by chromosome aberrations in interphase tumor nuclei by non-radioactive in situ

22 Arnoldus EPJ, Noordermeer IA, Peters ACB, Raap AK, Van der Ploeg $M$. Interphase cytogenetics reveals somatic pairing of chromosome 17 centromeres in normal human brain tissue, but no trisomy 7 or sex-chromosome loss. Cytogenet Cell Genet 1991;56:214-6. 